Article

\title{
Detection of Organochlorine Pesticide (OCPs) Residues and Trace Metals in Some Selected Malt Drinks in Nigeria
}

\author{
Godwin O. Olutona * (D) and Sophia Toluwalogo Livingstone \\ Department of Chemistry and Industrial Chemistry, Bowen University, Iwo 232102, Nigeria; \\ justsopheeya@gmail.com \\ * Correspondence: delog2@gmail.com; Tel.: +234-813-240-6932
}

Received: 2 August 2018; Accepted: 21 August 2018; Published: 1 September 2018

\begin{abstract}
In this study we evaluated the trace metals and toxic residues of pesticides in commercial malta drinks sold in Nigeria markets. Residual concentrations of seventeen (17) chlorinated hydrocarbons and trace metals were determined in fifteen samples of three batches each of five selected brands of Malta drink sold in Nigeria markets. Gas Chromatograph-Electron Capture Detector (GC-ECD) and Atomic Absorption Spectrophotometry (AAS) were employed in quantitative analysis. The results revealed that all the malt drink analyzed have one or more OCPs detected. The presence of eleven (11) OCPs residue were detected at varying concentrations. The total burden of OCPs in the samples was in the following order: AMS > DUB > MAG > HIM > MLT. Trace metals results revealed that $\mathrm{Cd}$ was below detection limit in all the samples while $\mathrm{Pb}$; $\mathrm{Ni}$ and $\mathrm{Cr}$ were above World Health Organization and United State Environmental Protection Agency (WHO/USEPA) limits for drinking water.
\end{abstract}

Keywords: beverages; persistent organic pollutants; toxicology; contamination; toxic metals; public health

\section{Introduction}

Beverages are consumed in Nigeria regardless of age, gender and socio-economic background and play a vital function in refreshing and improving life. Contaminated and or expired beverages have capability to cause disease when they are consumed [1]. Manufacture of beverages normally involves the use of plant- based product as an active ingredient.

Malt drinks are beverages brewed from barley, hops, sorghum and water. Malt drinks are rich in minerals and multivitamins such as vitamins A, B, B2, B3, B5, B6 and calcium which provide nourishment to the body [2]. Malt beverages were originally brewed to be used as food for children and the sick due to the high nutritional content. However, it is now a popular beverage consumed by people of all ages [2].

Beverages are consumed during ceremony, leisure, sport and during or after hard work as refreshment and/or to quench thirst. The intake of these non-alcoholic beverages in Nigeria was rated at 159.85 g/person/day in 2007, $58 \mathrm{kcal} /$ capita/day in 2011, $261 \mathrm{kcal} / \mathrm{capita} /$ day in 2012 and $246 \mathrm{kcal} / \mathrm{capital} /$ day in 2013 [3].

Nigerian brewers have set their gaze upon sorghum, one of the main ingredients in the production of malt drinks and an important cereal crop. Cereal such as millet and sorghum are mainly cultivated in the northern part of Nigeria. It is rich in mineral nutrients (such as iron, magnesium, thiamin, phosphorous, potassium, copper, riboflavin and calcium) which have various health benefits; hence, sorghum is economically beneficial. Due to this discovery, Sorghum is now being greatly exploited and used in place of barley for brewing malt drinks [4]. 
The World Health Organization (WHO, 2017) [5] defined a pesticide as a chemical compound that is used to kill pests, including insects, rodents, fungi and unwanted plants (weeds). The Food and Agriculture Organization (FAO) of the United Nations defined a pesticide as any substance or mixture of substances intended for preventing, destroying, or controlling any pest, including vectors of human or animal diseases, unwanted species of plants or animals causing harm during, or otherwise interfering with, the production, processing, storage, or marketing of food, agricultural commodities, wood and wood products, or animal feedstuffs, or which may be administered to animals for the control of insects, arachnids or other pests in or on their bodies [6]. Pesticides are used in the cultivation of crops to prevent or control pests and other pathogens responsible for losses and low-quality produce. Pesticides, therefore, improve yield as well as quality and appearance of the produce [7]. While pesticides have positive effects on plants, many of them are harmful to human beings, this is because they are intended to be a poison. Pesticides find their way into the food chain by the direct application of the substance on plants. They have various modes of entry into the human body such as inhalation (respiratory entry), ingestion (oral entry) and dermal entry (penetration through the skin) [8].

Pesticides possess the ability to bioaccumulate (increase in concentration in an organism's body) and biomagnify (increase in concentration up the food chain). This ability makes them even more dangerous because they can be retained in an organism's body for a long period of time. Pesticides can be classified by chemical structure (e.g., organic, inorganic and synthetic) or are grouped into chemical families such as organochlorines, organophosphates and carbamates [9].

The use of some pesticides and organic matter have been banned due to their toxicity, however, more agricultural aids are being discovered, each with their "pros and cons". Therefore, as it is impossible to ban the use of all chemicals which threaten human health in the slightest way, regulatory tests and boards have been set up to monitor and control these substances in the best possible way.

Organochlorines, also referred to as chlorinated hydrocarbons, are organic compounds that contain at least one covalently bonded atom of Chlorine. Organochlorines, due to their structural variety, have a broad range of uses and applications, however, some are of great environmental concern [10]. Organochlorine compounds can be found in nearly every class of biomolecules and can be produced naturally by forest fires, biological decomposition and volcanoes or from organisms such as bacteria and algae [11].

The biggest application of Organochlorines is as a pesticide. The most infamous organochlorine pesticide is Dichlorodiphenyltrichloroethane, DDT. Organochlorines, like most pesticides, are persistent and toxic to biological organisms. They resist chemical and biological degradation [12], have high lipophilic affinity [13] and have the ability to bioaccumulate and biomagnify [14]. Organochlorine pesticides were used extensively from the 1940s through the 1960s in agriculture and mosquito control, and were later banned in the United States. Short term exposure to organochlorine pesticides may cause headaches, dizziness, convulsions, nausea, and muscle weakness, slurred speech, vomiting and sweating. Long term exposure causes more serious conditions such as damage to the liver, kidney, central nervous system, thyroid, and bladder.

The use of agricultural pesticides for agricultural production has led not only to the increase in yield, but also increase in environmental pollution. The dangerous characteristics of pesticides such as long half-life, bioaccumulation and high lipophilicity enables them to remain in the environment after many years of application. A study by Pimentel [15] showed that only $0.3 \%$ of applied pesticides goes into the target pest while $99.7 \%$ goes into the environment. This has adverse effects on the environment, human and animal's health.

Persistent organic pesticide residues are widely distributed in Nigerian soil, water and cultivated crops especially cereals like barley and sorghum. Dichlorodiphenyltrichloroethane, DDT, and Hexachlorocyclohexane, $\mathrm{HCH}$, have been restricted from use in Nigeria as a result of their adverse effects. However, despite the ban, these chemicals (e.g., y-HCH) are still being used by farmers on a large-scale Nigeria and a few other countries [16]. 
Soil is the foremost basin of persistent organic pesticides and plays significant part in the worldwide input and fate of OCPs, in addition to their large retention capacity they also re-emit this organic pollutant into the atmosphere, groundwater and living organisms as secondary source [17]. The inference of this in agriculture is the entrance of OCPs into growing plants and persistence of their residues [17]

Trace metals or trace elements are elements that normally occur at very low levels or concentrations in the environment [18]. Very small amounts of some of these metals are beneficial and essential for human beings, however, high concentrations of these same metals can be toxic.

Trace metals can reach agricultural lands through different routes and affect the soil, and cause serious problems to human health [19]. The use of organic wastes is the most common and significant way by which agricultural soils can be contaminated by trace metals. Municipal wastewaters are used for agriculture irrigation [20]. They contain low concentrations of heavy metals, however, long-term use of these wastewaters for irrigation often results in the buildup of metals in soils [21]. These metals are taken up by the plants via their roots and are usually soluble ions in the form of organic or inorganic complexes. The concentrations, type and chemical nature of the complexes determine the plant's ability to accumulate the trace metals [22].

All metals are toxic at high concentrations and excessive levels can be damaging to the organism [23]. These metals could be built up in different parts of human body such as heart, kidney, liver, blood and spleen whereby they cause diseases capable of causing damage to human body [24]. In biological systems, heavy metals have been reported to affect cellular organelles and components such as cell membrane, mitochondrial, lysosome, endoplasmic reticulum, nuclei, and some enzymes involved in metabolism, detoxification, and damage repair [25]. Metal ions have been found to interact with cell components such as DNA and nuclear proteins, causing DNA damage and conformational changes that may lead to cell cycle modulation, carcinogenesis or apoptosis $[26,27]$.

Thus, it is necessary to look into these malt drinks to determine whether or not they are safe for consumption. The consumers need to be re-assured that these beverages are free from pesticide residues and other toxic substances.

\section{Materials and Methods}

\subsection{Sampling}

Five different brands (MAG, DUB, HIM, MLT and AMS) of locally produced malt drinks were randomly chosen out of about twelve different brands of malt drinks available for sales in Nigerian markets. Three samples of each brand having different batch numbers were purchased from the local supermarkets in Iwo, Osun state, Nigeria. A total of fifteen samples were collected and analyzed. The content of these drinks is water, sucrose, malted barley, malted sorghum, sorghum, caramel, hops, calcium, Vitamins A, B1, B2, B3, B5 and C, natural flavor and foam stabilizer. Others specific ingredients are citric acid (HIM), carbonated water (MAG) and sugar (DUB).

\subsection{Reagent Used and Their Sources}

Acetone, nitric acid and perchloric acid were purchased from Park Scientific Ltd. (Northamptom, UK); dichoromethane, n-hexane from GFS chemicals, (Inc Colombus, Powell, Ohio, USA); anhydrous sodium sulphate from BDH, (Poole England); and Silical gel (silica gel 60, particle size 0.063-0.200 mm, 7-230 mesh) from Lab Tech Chemicals (Boksburg, Guateng, South Africa).

\subsection{Trace Metal Analysis}

The trace metals determined are zinc, copper, chromium, cadmium, nickel, and lead. This was achieved by digesting $50 \mathrm{~mL}$ of each sample using $5 \mathrm{~mL}$ of nitric acid and $1 \mathrm{ml}$ of perchloric acid. The digested samples were reduced to a volume of about $2 \mathrm{~mL}$ and made up to the mark with distilled water in $25 \mathrm{~mL}$ standard flask. The digested solutions were analyzed via Atomic Absorption Spectroscopy at the National Institute of Oceanography, Victoria Island, Lagos, Nigeria. 


\subsection{Extraction Procedure for OCPS}

The OCPs were extracted from malt samples by separating funnel method. Composite sample of the three batches of each brand of the malt drinks were made and about $500 \mathrm{~mL}$ of the samples were each decanted into a clean separating funnel and $30 \mathrm{~mL}$ of Dichloromethane was added to it. CThe separating funnel was then carefully agitated for twenty minutes. After agitation, the sample was left to settle and the OCPs were extracted from malt samples. This process was repeated three times for each sample to ensure maximum extraction of the OCPs.

\subsection{Clean-up Procedure for $\mathrm{OCPs}$}

The Clean-up method, USEPA Method 3630C, was used in this study. A column of $15 \mathrm{~cm} \times$ $1 \mathrm{~cm}$ (internal diameter) was packed with $5 \mathrm{~g}$ of activated silica gel. One $(1 \mathrm{~g})$ of anhydrous Sodium Sulphate was placed at the top of the column and Dichloromethane was added to condition it and cause elution to occur. The eluate was collected and evaporated to dryness.

\subsection{Validity of Analytical Methods for Trace Metals and OCPs}

Calibration curve for trace metal were plotted at various concentrations $(0.2,0.5,1.0,2.0,4.0 \mathrm{mg} / \mathrm{L})$ from stock solution. Stock solution was prepared from standard reference materials $(1000 \mathrm{mg} / \mathrm{L})$. The linear calibration obtained were $\mathrm{Zn}$ (0.99952), $\mathrm{Pb}$ (0.99962), Ni (0.99993), Cd (0.99958), and Cu (0.99986). The precision of the method was proven with an estimation of the percentage residual standard. Limit of detection (LOD) and limit of quantification (LOQ) for trace metals $(\mathrm{mg} / \mathrm{L})$ are $\mathrm{Cu}(0.0024,0.024), \mathrm{Ni}(0.0105$, 0.105), $\mathrm{Zn}(0.0009,0.009), \mathrm{Cd}(0.0028,0.028), \mathrm{Cr}(0.005,0.05)$ and $\mathrm{Pb}(0.012,0.12)$.

The limit of detection (LOD) for OCPs were obtained at a signal-to-noise ratio (S/N) of three replicates while that of limit of quantification (LOQ) at $\mathrm{S} / \mathrm{N}$ ratio of ten replicates for each pesticide, respectively. Standard addition method was employed to validate the analytical method employed in this study. The linearity of the analytical method was appraised using a concentration range of pesticide residues analyzed by GC-ECD. The calibration curve was plotted with the standard solution in n-hexane containing four different concentrations $(0.1,0.25,0.5,1.0 \mathrm{ng} / \mu \mathrm{L})$. In all the several cases, good linearity was attained with correlation coefficient $>0.995$. The malt drink samples were spiked with $(1,2,5 \mu \mathrm{g} / \mathrm{L})$ mixed OCP standard solution. The spiked samples were permitted to stand for some hours before extraction. This was followed by cleanup and subsequent GC-ECD analysis. Replicate analysis was carried out and the percentage recovery for each compound were determined. Linearity was determined by plotting the calibration curve with the standard solution in n-hexane containing four different concentrations $(0.1,0.25,0.5,1.0 \mathrm{ng} / \mu \mathrm{L})$.

\subsection{Chromatography-Electron Capture Detector condition}

Gas Chromatography from the Central Laboratory, National Institute of Oceanography and Marine Research (NIOMR), Victoria Island, Lagos, Nigeria, was used to determine the concentrations of organochlorine pesticide residues in the samples. The dried eluate was reconstituted with $0.5 \mathrm{~mL}$ hexane and $0.5 \mathrm{~mL}$ of $20 \mathrm{ppm}$ of the internal standard. The analysis of the OCPs was carried out with the aid Agilent 7890A GC-ECD. The levels of OCP was obtained from the relationship given below.

$$
\text { Concentration of analyte }(\mathrm{ng} / \mathrm{g})=\frac{\text { Concentration of analyte }\left(\frac{\mathrm{ng}}{\mathrm{mL}}\right) \times \text { volume }(\mathrm{mL}) \times \text { dilution factor }}{\text { Sample weight }(\mathrm{g})}
$$

The system was fitted with DB $17(30 \mathrm{~m} \times 250 \mu \mathrm{m} \times 0.25 \mu \mathrm{m})$ Agilent column. A $1 \mu \mathrm{L}$ aliquot of measured sample extract was injected into the column in splitless mode at an injector and interface temperature of $250{ }^{\circ} \mathrm{C}$. A flow rate of $2 \mathrm{~mL} / \mathrm{min}$ was obtained and the initial temperature of $150{ }^{\circ} \mathrm{C}$ was ramped to $280^{\circ} \mathrm{C}$ at $6{ }^{\circ} \mathrm{C} / \mathrm{min}$ in the oven. The detector temperature was $290^{\circ} \mathrm{C}$ and the total run time was $21.67 \mathrm{~min}$. 


\subsection{Data Analysis}

The raw data were subjected to descriptive analysis and one-way analysis of variance using Statistical Package for Social Science (SPSS) (IBM Corporation, Armonk, United Kingdom)

\section{Results and Discussion}

\subsection{Trace Metals}

This section presents the results and discussion of the research work carried out on the determination of trace metals and organochlorines in some malt samples. Table 1 presents the mean concentrations of trace metals in malt drinks.

Table 1. Mean Concentration of Trace Metals (mg/L) in Malt Drinks.

\begin{tabular}{ccccccc}
\hline Type of Drink & $\mathbf{C d}$ & $\mathbf{C u}$ & $\mathbf{C r}$ & $\mathbf{N i}$ & $\mathbf{P b}$ & $\mathbf{Z n}$ \\
\hline AMS & ND & $0.044 \pm 0.001$ & ND & $0.22 \pm 0.001$ & $0.072 \pm 0.001$ & $0.106 \pm 0.002$ \\
DUB & ND & $0.092 \pm 0.001$ & $0.1 \pm 0.000$ & $0.182 \pm 0.000$ & $1.058 \pm 0.006$ & $0.652 \pm 0.008$ \\
HIM & ND & $0.102 \pm 0.000$ & $0.002 \pm 0.000$ & $0.23 \pm 0.001$ & $1.116 \pm 0.000$ & $0.454 \pm 0.003$ \\
MAG & ND & $0.084 \pm 0.001$ & $0.246 \pm 0.000$ & $0.482 \pm 0.003$ & $0.344 \pm 0.002$ & $0.06 \pm 0.004$ \\
MLT & ND & $0.084 \pm 0.000$ & $0.698 \pm 0.001$ & $0.254 \pm 0.002$ & $0.518 \pm 0.003$ & $0.24 \pm 0.003$ \\
WHO & 0.005 & 2.0 & 0.05 & 0.02 & 0.01 & 5.0 \\
USEPA & 0.015 & 1.3 & 0.1 & 0.02 & 0.005 & - \\
\hline
\end{tabular}

(ND: Not Detected).

Copper, an essential element required for the growth and development of plants and animals and also the third most used metal in the world, was analyzed and found present in all the samples. The concentrations of copper were found to range from $(0.044 \mathrm{mg} / \mathrm{L})$ to $(0.102 \mathrm{mg} / \mathrm{L})$ which were below the WHO (2 mg/L) and USEPA $(1.3 \mathrm{mg} / \mathrm{L})$ limits for drinking water, respectively.

Chromium was found present in all the samples except Amstel. Cr concentration ranged from ND in AMS to $0.698 \mathrm{mg} / \mathrm{L}$ in MLT. Chromium is associated with allergic dermatitis and shouldn't be consumed in high concentrations. DUB and HIM, had Cr concentrations within the WHO (0.05 mg/L) and USEPA $(0.1 \mathrm{mg} / \mathrm{L})$ limits for drinking water, respectively. MAG and MLT concentrations exceeded the limits.

Nickel, a metal which can be really dangerous to human health at high doses, was analyzed and found present in all samples ranging from $(0.182 \mathrm{mg} / \mathrm{L})$ in DUB to $(0.482 \mathrm{mg} / \mathrm{L})$ in MAG. All the five brands had their Ni concentrations exceeding the WHO and USEPA limits for drinking water. DUB had the lowest $\mathrm{Ni}$ concentration of $(0.182 \mathrm{mg} / \mathrm{L})$ which was almost 10 times above the recommended limit.

Lead, was also found present in all the five brand samples at alarming concentrations well above the WHO and USEPA limits for drinking water. The Pb concentrations ranged from $(0.072 \mathrm{mg} / \mathrm{L})$ in AMS to $(1.116 \mathrm{mg} / \mathrm{L})$ in HIM. This could have serious adverse effects on humans such as brain damage and even death.

Zinc, a well-known essential metal, was found at really low concentrations. Drinking water and many foodstuffs contain certain concentrations of $\mathrm{Zn}$ due to its functions in the body. Although, high concentrations of $\mathrm{Zn}$ could affect the body negatively, it is advised that $\mathrm{Zn}$ intake should still be balanced. The $\mathrm{Zn}$ concentration ranged between $(0.06 \mathrm{mg} / \mathrm{L})$ in MAG to $(0.652 \mathrm{mg} / \mathrm{L})$ in DUB. The WHO limit for drinking water for $\mathrm{Zn}$ is $5.0 \mathrm{mg} / \mathrm{L}$ and the values obtained in this study were far below this limit.

In comparison of the results of this study with other studies, the concentrations of $\mathrm{Pb}, \mathrm{Ni}$, and $\mathrm{Cr}$ in the malt drinks were higher than the values reported by [2]. Salako et al. [28], reported $\mathrm{Pb}(0.001$ to $0.447 \mathrm{mg} / \mathrm{L}$ ), $\mathrm{Ni}$ (ND to $0.301 \mathrm{mg} / \mathrm{L}$ ), and $\mathrm{Cr}$ (ND to $0.026 \mathrm{mg} / \mathrm{L}$ ) in which case $\mathrm{Pb}$ and Ni exceeded WHO limits while $\mathrm{Cu}, \mathrm{Zn}$ and Cd values were below the WHO limits. Ogunlana et al. [29] carried out a research on heavy metal analysis of selected soft drink in Nigeria. The study revealed that $60 \%$ of the selected beverages have either/both $\mathrm{Pb}$ and as levels above the recommended limits while $10 \%$ of the samples have both $\mathrm{Pb}$ and $\mathrm{Cd}$ concentrations above the recommended limits. Engwa et al. [30] investigated the presence of some heavy metals and constituents of twenty-six soft drinks in Nigeria. 
Among the soft drinks evaluated were two brands each of canned and bottled Maltina and Amstel Malta drinks. Both bottled and canned Maltina had no traces of $\mathrm{Cd}$, but $\mathrm{Pb}$ and $\mathrm{Hg}$ were present. Bottled Maltina had $\mathrm{Pb}$ concentration $(0.731 \mathrm{mg} / \mathrm{L})$ higher than the values obtained in this study whereas, canned Maltina had lower Pb concentration $(0.260 \mathrm{mg} / \mathrm{L})$. Bottled and canned Amstel Malta also had no traces of $\mathrm{Cd}$, however, $\mathrm{Pb}$ was present in both with a concentration of $(0.256 \mathrm{mg} / \mathrm{L})$ in bottled Amstel Malta which was lower than the values obtained in this study while $(1.305 \mathrm{mg} / \mathrm{L})$ for canned Amstel Malta which was higher than the values obtained in this study. Al-Mudharf et al. [31] worked on trace and heavy metal contents of twenty-two brands of locally produced soft drinks other than malt drinks in Kuwait and seven brands imported from Jordan and Austria. None of the metals exceeded either the US EPA or the WHO maximum recommended levels for drinking water. It was concluded that soft drinks available in Kuwait are completely safe to drink with regard to toxic metals. Similar study conducted in Accra, Ghana on twenty bottles comprising of ten fruit juice and ten soft drinks other than malt drinks [32]. The maximum concentration of $\mathrm{Pb}$ detected in the soft drinks was $2.78 \mathrm{mg} / \mathrm{L}$ which is above the safe limit of $0.01 \mathrm{mg} / \mathrm{L}$. Elbagermi et al. [33] analyzed $\mathrm{Pb}, \mathrm{Fe}, \mathrm{Cu}, \mathrm{Zn}$ and $\mathrm{Cd}$ in 50 canned soft drinks purchased from several regions in Misurata, Libya. The Pb concentration is lower than that reported in this study, however, $\mathrm{Cu}, \mathrm{Zn}$ and $\mathrm{Cd}$ concentrations were higher.

\subsection{Organochlorine Pesticides Residues}

Chromatogram of the OCPs mix standard (2 ppm) and representative chromatogram of OCPs of the malt drink samples analyzed is shown in Figure $1 \mathrm{a} \& \mathrm{~b}$, respectively. There was no interference among the peaks obtained for the chromatogram of the blank sample. Table 2 presents the retention time, limit of detection (LOD), limit of quantification (LOQ), response factor, and percentage mean recovery analysis of some of the OCPs congeners. The retention time range from $\alpha \mathrm{BHC}(5.030 \mathrm{~min})$ to methoxychlor (19.371 $\mathrm{min}$ ). The LOD and LOQ values ranged from $0.023-0.405 \mathrm{ng} / \mu \mathrm{L}$ and 0.23 and $4.05 \mathrm{ng} / \mu \mathrm{L}$, respectively. The mean percentages recoveries analysis ranges from endrin $(81.76 \%)$ to $\mathrm{p}, \mathrm{p}^{\prime}$ DDD $(94.8 \%)$. The mean \% recoveries values attained in this study fall within $70-110 \%$ standard range for recovery as specified by EU guideline for assessing precision and accuracy of analytical method [34]. This implies that the analytical method employed in this study is efficient, reliable and reproducible.

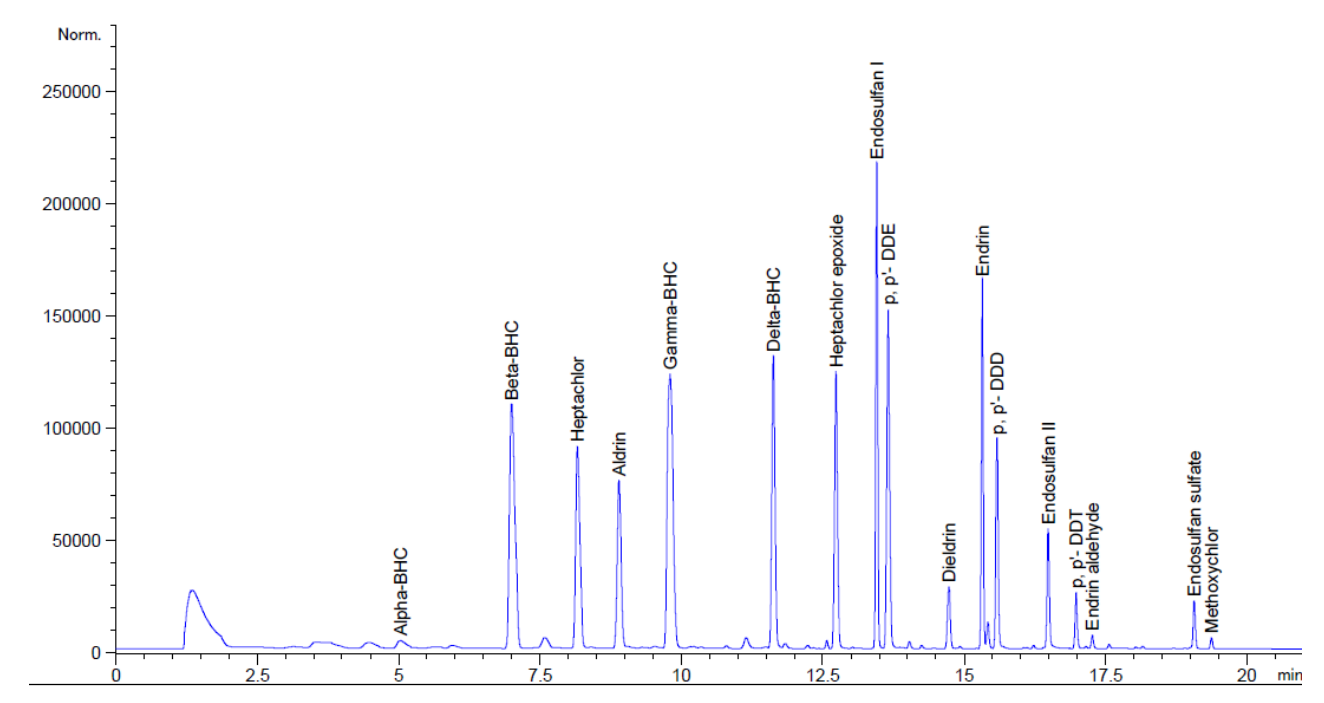

(a)

Figure 1. Cont. 


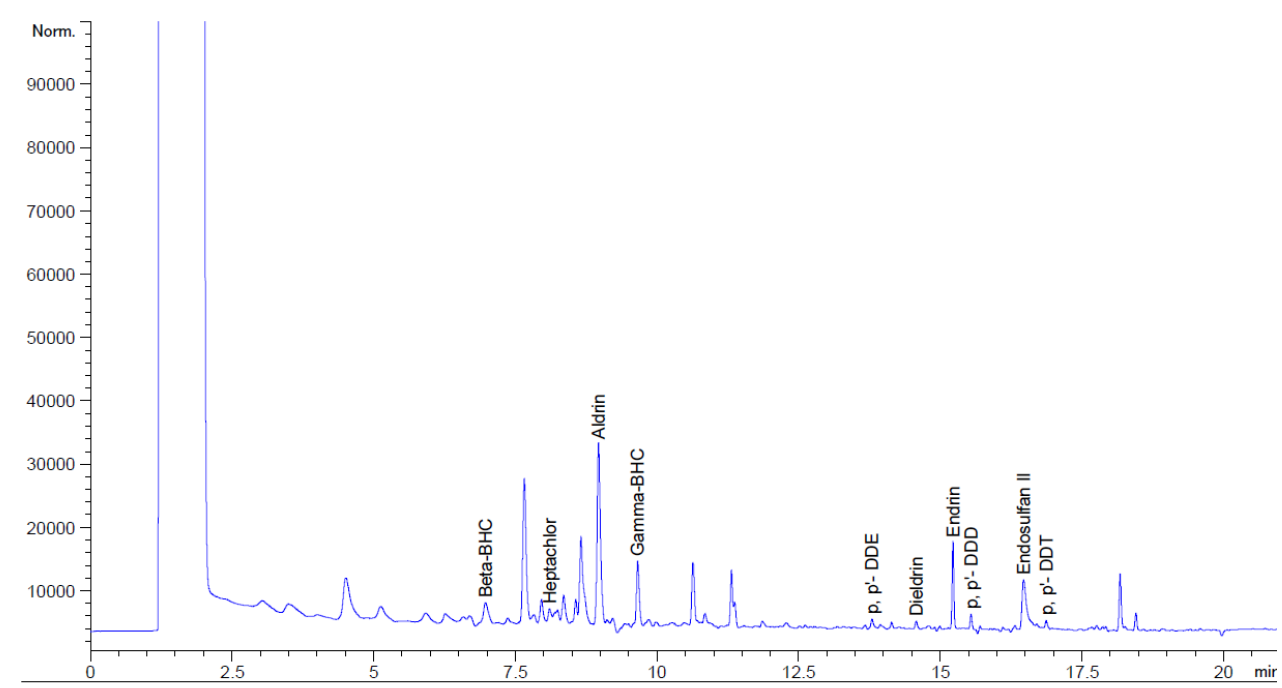

(b)

Figure 1. (a) Chromatogram of the OCPs mix standard; (b) Representative chromatogram of the samples analyzed in this study.

Table 2. Retention Time, LOD, LOQ and \% Recovery for OCPs.

\begin{tabular}{|c|c|c|c|c|c|}
\hline OCPs & Retention Time (min) & LOD $(n g / \mu L)$ & LOQ (ng/ $\mu \mathrm{L})$ & Recovery (\%) & Response factor \\
\hline$\alpha \mathrm{BHC}$ & 5.030 & 0.065 & 0.65 & $87.68 \pm 4.54$ & \\
\hline$\beta B H C$ & 6.996 & 0.094 & 0.94 & $86.77 \pm 6.54$ & $1.78 \pm 0.01$ \\
\hline Heptachlor & 8.159 & 0.094 & 0.94 & $90.20 \pm 4.75$ & $1.33 \pm 0.02$ \\
\hline Aldrin & 8.894 & 0.031 & 0.31 & $85.56 \pm 4.61$ & $1.04 \pm 0.02$ \\
\hline$\lambda \mathrm{BHC}$ & 9.796 & 0.057 & 0.57 & $90.16 \pm 4.38$ & $1.44 \pm 0.01$ \\
\hline$\delta \mathrm{BHC}$ & 11.624 & 0.017 & 0.17 & $89.35 \pm 4.56$ & $1.24 \pm 0.01$ \\
\hline Heptachlor epoxide & 12.732 & 0.023 & 0.23 & $92.79 \pm 2.56$ & \\
\hline Endosulfan I & 13.452 & 0.060 & 0.60 & $86.35 \pm 5.77$ & \\
\hline $\mathrm{p}, \mathrm{p}^{\prime} \mathrm{DDE}$ & 13.654 & 0.040 & 0.40 & $91.25 \pm 3.45$ & $1.61 \pm 0.01$ \\
\hline Dieldrin & 14.727 & 0.071 & 0.71 & $81.78 \pm 5.46$ & $3.41 \pm 0.02$ \\
\hline Endrin & 15.318 & 0.112 & 1.12 & $81.76 \pm 4.39$ & $1.14 \pm 0.01$ \\
\hline $\mathrm{p}, \mathrm{p}^{\prime} \mathrm{DDD}$ & 15.578 & 0.082 & 0.82 & $94.81 \pm 3.67$ & $1.87 \pm 0.02$ \\
\hline Endosulfan II & 16.483 & 0.141 & 1.41 & $88.67 \pm 3.05$ & $1.09 \pm 0.01$ \\
\hline $\mathrm{p}, \mathrm{p}^{\prime} \mathrm{DDT}$ & 16.978 & 0.078 & 0.78 & $92.44 \pm 4.58$ & $1.41 \pm 0.01$ \\
\hline Endrin $\mathrm{CHO}$ & 17.265 & 0.057 & 0.57 & $93.31 \pm 3.85$ & \\
\hline Endosulfan sulphate & 19.066 & 0.122 & 1.12 & $90.76 \pm 5.68$ & \\
\hline Methoxychlor & 19.371 & 0.405 & 4.05 & $91.98 \pm 4.54$ & \\
\hline
\end{tabular}

Table 3 presents mean concentrations of cyclodienes isomers in malt drink. Three cyclodienes pesticides (Hept-epoxide, endrin aldehyde, endosulfan I) were absent in all the selected malt drinks. Residue of cyclodiene derivatives revealed Heptachlor and Aldrin, were present in all samples except MLT. Their ranged values are: heptachlor (ND-0.336 mg/kg), and aldrin (ND-1.272 mg/kg). The concentrations of heptachlor obtained in this present study were above the MRLs of $0.02 \mathrm{mg} / \mathrm{kg}$ of heptachlor in food substances. The presence of heptachlor in these malt drinks revealed that farmers in Nigeria engaged the use of heptachlor in sorghum production. Aldrin $(1.272 \mathrm{mg} / \mathrm{kg})$ had the highest concentration in AMS. The aldrin residue levels recorded in this study were above the EU-MRls of $0.05 \mathrm{mg} / \mathrm{kg}$. Endrin (0.363) was only found in AMS but this value was above the $0.01 \mathrm{mg} / \mathrm{kg}$ listed in the EU MRLs for endrin in food substances. Endosulfan II was the most predominant cyclodienes with ranged value $(0.57$ and $0.99 \mathrm{mg} / \mathrm{kg}$ ) and above MRL value of $0.10 \mathrm{mg} / \mathrm{kg}$. Endosulfan-sulphate was not detected in all the samples analyzed in this study. 
The relationship between environmental endosulfan I exposure and reproductive development in male children and adolescent was carried out by Saiyed et al. [35]. Their studied revealed that endosulfan exposure in male children may delay sexual maturity and interfere with sex hormone synthesis. Analysis of OCPs residue in maternal and cord blood of women of Full Term delivery (FTD) and Pre-Term Delivery (PTD) group were carried out by Pathek et al. [36] and observed higher levels of $\beta \mathrm{BCH}$, endosulfan, increased oxidative stress in PTD and FTD case.

Table 3. Mean concentrations of cyclodienes $(\mathrm{mg} / \mathrm{kg})$ isomers in Malt Drink.

\begin{tabular}{ccccccc}
\hline OCPs & AMS & DUB & HIM & MAG & MLT & MRL \\
\hline Heptachlor & $0.17 \pm 0.050$ & $0.34 \pm 0.003$ & $0.20 \pm 0.002$ & $0.29 \pm 0.002$ & ND & 0.02 \\
Hept-epoxide & ND & ND & ND & ND & ND & 0.02 \\
Aldrin & $1.272 \pm 0.001$ & $1.02 \pm 0.001$ & $0.20 \pm 0.001$ & $0.29 \pm 0.001$ & ND & 0.05 \\
Dieldrin & $0.22 \pm 0.003$ & $0.21 \pm 0.010$ & ND & ND & ND & 0.02 \\
Endrin & $0.363 \pm 0.005$ & ND & ND & ND & ND & 0.01 \\
Endrin CHO & ND & ND & ND & ND & ND & 0.01 \\
Endosulfan I & ND & ND & ND & ND & ND & 0.10 \\
Endosulfan II & $0.99 \pm 0.012$ & $0.66 \pm 0.006$ & $0.51 \pm 0.004$ & $0.62 \pm 0.006$ & $0.64 \pm 0.002$ & 0.10 \\
\hline
\end{tabular}

Table 4 presents mean concentrations of dichloro diphenylethanes. Methoxychor was not detected in all the selected malt drink. The residue levels of three dichloro diphenyl ethane isomers revealed that $\mathrm{p}, \mathrm{p}^{\prime}$-DDD ranged (ND-0.128 mg/kg) and detected only in MLT while $\mathrm{p}, \mathrm{p}^{\prime}$-DDE (0.053) and p, $\mathrm{p}^{\prime}$-DDT (0.247) were only found present in AMS and were also above the MLR standard limit. The concentrations of dichloro diphenylethanes from this study were above the EU-MRL of $0.05 \mathrm{mg} / \mathrm{kg}$ in food.

Table 4. Mean concentrations of dichloro diphenylethene $(\mathrm{mg} / \mathrm{kg})$ isomers in Malt Drink.

\begin{tabular}{ccccccc}
\hline OCPs & AMS & DUB & HIM & MAG & MLT & MRL \\
\hline p, p'-DDD & $0.128 \pm 0.002$ & $0.11 \pm 0.002$ & $0.098 \pm 0.003$ & $0.11 \pm 0.010$ & ND & 0.05 \\
p, p-DDE & $0.053 \pm 0.020$ & ND & ND & ND & ND & 0.05 \\
p, p-DDT & $0.247 \pm 0.003$ & ND & ND & ND & ND & 0.05 \\
Methoxychlor & ND & ND & ND & ND & ND & 0.01 \\
\hline
\end{tabular}

The mean concentrations of hexachloro cyclohexane in some selected malt drinks are shown in Table 5. The $\alpha$-BHC was no detected in all the selected malt drinks. The residue of hexachloro cyclohexane isomers revealed that $\beta$-BHC was present in all samples except MLT, ranged between (ND and $0.159 \mathrm{mg} / \mathrm{kg}$ ) and the value was above MRLs of $0.05 \mathrm{mg} / \mathrm{kg}$. $\delta$-BHC was only detected in MLT with a concentration $(0.113 \mathrm{mg} / \mathrm{kg})$ which was almost three times as much as its MRL of $0.05 \mathrm{mg} / \mathrm{kg}$. Dieldrin was detected in AMS $(0.22 \mathrm{mg} / \mathrm{kg})$ and DUB $(0.21 \mathrm{mg} / \mathrm{kg})$ levels, respectively. These also exceeded the MRL of $0.02 \mathrm{mg} / \mathrm{kg}$. $\lambda$-BHC was also found to be present in all sample with ranged value of $(0.083-0.20 \mathrm{mg} / \mathrm{kg})$ and above MRL value of $0.05 \mathrm{mg} / \mathrm{kg}$. The presence of these pesticides is an indication sorghum farmer in Nigeria engaged in actively use of lindane.

Table 5. Mean concentration of hexachloro cyclohexane $(\mathrm{mg} / \mathrm{kg})$ isomers in Malt Drinks.

\begin{tabular}{ccccccc}
\hline OCPs & AMS & DUB & HIM & MAG & MLT & MRL \\
\hline$\alpha$-BHC & ND & ND & ND & ND & ND & 0.05 \\
$\beta-B H C$ & $0.16 \pm 0.003$ & $0.134 \pm 0.003$ & $0.125 \pm 0.003$ & $0.133 \pm 0.002$ & ND & 0.05 \\
$\delta$-BHC & ND & ND & ND & $0.11 \pm 0.002$ & ND & 0.05 \\
$\lambda$-BHC & $0.02 \pm 0.012$ & $0.15 \pm 0.003$ & $0.13 \pm 0.004$ & $0.15 \pm 0.010$ & $0.083 \pm 0.004$ & 0.05 \\
\hline
\end{tabular}

The total mean concentrations of OCPs was presented in Table 6. Based on this, the five brands of malt drinks analyzed were arranged in order of increasing toxicity with MLT having the lowest total 
concentration $(0.833 \mathrm{mg} / \mathrm{kg})$ and AMS with the highest total concentration $(3.803 \mathrm{mg} / \mathrm{kg})$. The order goes thus, MLT < HIM < MAG < DUB < AMS.

Table 6. Mean total concentrations ( $\mathrm{mg} / \mathrm{kg}$ ) OCPs in selected malt drink.

\begin{tabular}{ccccc}
\hline AMS & DUB & HIM & MAG & MLT \\
\hline $3.80 \pm 0.04$ & $2.66 \pm 0.06$ & $1.32 \pm 0.02$ & $1.59 \pm 0.03$ & $0.83 \pm 0.01$ \\
\hline
\end{tabular}

Analysis of seven cocoa-based beverages in Nigeria for Persistent Organochlorine Pesticide Residues was carried out by Ibigbami and Adeboware [37]. Fourteen (14) samples, two samples for each brand of cocoa beverage, were purchased at a Supermarket in Ado-Ekiti, South-Western Nigeria, and the selection was based on the availability of the samples at the point of purchase. The concentration of BHCs ranges from (ND-0.005 $\mathrm{mg} / \mathrm{kg}$ ) whereas, in this study, ranges from (ND-0.2 mg/kg) which is greater. The dichlorodiphenylethanes level range from (ND-0.118 mg/kg). The DDT concentrations were found to be above the European Union Maximum Residue Limit (EU-MRL) of $0.050 \mathrm{mg} / \mathrm{kg}$ in food. The cyclodienes (heptachlor, Aldrin, dieldrin, endrin, endosulfan II) were detected to have a concentration range of (ND-0.256 mg/kg). In this study, the dichlorophenylethanes and cyclodienes are seen to be far greater than the results Ibigbami and Adeboware [37] reported with values ranging from (ND-0.25 mg/kg) and (ND-1.27 mg/kg).

An appraisal of pesticide residues in Kola Nuts obtained from selected markets in Southwestern, Nigeria was carried out by Aikpokpodion et al. [38] from the Cocoa Research Institute of Nigeria. Kola nuts are widely used as a stimulant and raw materials for soft drinks (Coca cola and Pepsi), hence, it is important to determine the level of pesticide residues to determine whether or not they are fit for consumption, and what can be done to reduce the level of toxicity. The results obtained showed that $50 \%$ of kola nut samples obtained from Oyo state contained chlordane residue ranging from (ND-0.123 $\mathrm{mg} / \mathrm{kg}$ ); all the samples from Osun state had chlordane residue ranging from $(0.103-0.115 \mathrm{mg} / \mathrm{kg})$ while $70 \%$ of kola nuts from Ogun state had chlordane residues from (ND-0.12 mg/kg). All samples from Ogun, Osun and Oyo states had endosulfan residues while 30 and $20 \%$ of kola nuts obtained from Osun and Ogun states had alachlor residues respectively [38].

\section{Conclusions}

This study indicated the occurrence of OCPs with varying concentrations in the selected malt drink with AMS having the highest mean total burden of pesticides residue. The order goes thus, MLT $<$ HIM $<$ MAG $<$ DUB $<$ AMS. Most of the OCPs revealed very high concentrations of OCPs in the selected malt drinks above the EU-MRLs in food. Endosulfan II was the most predominant cyclodienes and above MRL value as stipulated by EU. Moreover, trace metals results revealed that $\mathrm{Cd}$ was below detection limit in all the samples while $\mathrm{Cu}$ and $\mathrm{Zn}$ below WHO/USEPA limits. Pb, Ni and $\mathrm{Cr}$ were above WHO/USEPA limits for drinking water. These chlororganic pesticides residues are persistent in nature and have ability to undergo long range atmospheric fronts away from where they are used. Their presence in food chain as a result of long term exposure via food intake has been correlated with severe neurological developmental disorder, endocrine, reproductive, immune system, and infertility. The government are therefore advised to discourage farmers from using pesticides in their farming activities. Enforcement of banned pesticides products is highly recommended. The regulatory bodies and manufacturers should intensify constant monitoring of pesticides in sorghum previously being processed for malt drink. Moreover, it is also thus recommended that, alternative pesticides which are safe, biodegradable and environmentally friendly should be sought for the purpose of sorghum plantation and preservation.

Author Contributions: The corresponding author designed, supervised the experiment, analyzed the data and wrote the manuscript. LST carried out the experiment and took part in literature review.

Funding: This research received no external funding

Conflicts of Interest: The authors declare no conflict of interest. 


\section{Abbreviations}

$\begin{array}{ll}\text { BHC } & \text { Benzene hexachloride } \\ \text { ECD } & \text { Electron Capture Detector } \\ \text { Endrin CHO } & \text { Endrin Aldehyde } \\ \text { EU } & \text { European Union } \\ \text { LOD } & \text { Limit of Detection } \\ \text { LOQ } & \text { Limit of Quantification } \\ \text { ND } & \text { Not Detected } \\ \text { OCPs } & \text { Organochlorine Pesticides Residue } \\ \text { p, p'-DDD } & \text { Para, para-dichlorodiphenyldichloroethane } \\ \text { p, p'-DDE } & \text { Para, para-dichlorodiphenylchloroethylene } \\ \text { p, p'-DDT } & \text { Para, para-dichlorodiphenyltrichloroethane } \\ \text { USEPA } & \text { United State Environmental Protection Agency }\end{array}$

\section{References}

1. Izah, S.C.; Inyang, I.R.; Angaye, T.C.N.; Okowa, I.P. A review of heavy metal concentration and potential health Implications of beverages consumed in Nigeria. Toxics 2017, 5, 1. [CrossRef] [PubMed]

2. Obuzor, G.U.; Ajaezi, N.E. Nutritional content of popular malt drinks produced in Nigeria. Afric. J. Food Sci. 2010, 4, 585-590.

3. FAO (United Nations Food and Agriculture Organization) FAOSTAT data. Available online: http:/ / faostat. fao.org (accessed on 10 August 2018).

4. Okojie, J. Nigerian brewers dump barley for sorghum in hunt for local substitute. Business Day Newspaper. Available online: https:/ / www.businessdayonline.com/exclusives/article/nigerian-brewers-dump-barleysorghum-hunt-local-substitute/ (accessed on 24 October 2017).

5. World Health Organization Health. Health Topics: Pesticides. Available online: http://www.who.int/ topics/pesticides/en (accessed on 10 August 2018).

6. Li, Z.; Jennings, A. Worldwide regulations of standard values of pesticides from human health risk control: A review. Int. J. Environ. Res. Pub. Health 2017, 14, 826. [CrossRef] [PubMed]

7. Cooper, J.; Dobson, H. The benefits of pesticides to mankind and the environment. Crop. Protect. 2007, 26, 1337-1348. [CrossRef]

8. Hicks, B. Agricultural pesticides and human health. In National Association of Geoscience Teachers; 2013; Available online: http:/ / serc.carleton.edu/NAGTWorkshops/health/case_studies/pesticides.html (accessed on 10 August 2018).

9. Kamrin, M.A. Pesticides profiles: Toxicity, environmental impact and fate; CRC Press: Boca Raton, FL, USA, 1997.

10. Rossberg, M.; Lendle, W.; Pfleiderer, G.; Togel, A.; Dreher, E.-L.; Langer, E.; Raaaaerts, H.; Kleinschmidt, P.; Strack, H.; Cook, R.; et al. "Chlorinated Hydrocarbons" in Ullmann's Encyclopedia of Industrial Chemistry. Wiley-VCH: Weinheim, Germany, 2000. [CrossRef]

11. Gribble, G.W. Naturally occurring organohalogen compounds. Acct. Chem Res. 1998, 31, 141-152. [CrossRef]

12. Afful, S.; Anim, A.; Serfor-Armah, Y. Spectrum of Organochlorine Pesticide Residues in Fish Samples from the Densu Basin. Res. J. Environ. Earth Sci. 2010, 2, 133-138.

13. Lopez, S.; Davies, D.R.; Giraldez, F.J.; Dhanoa, M.S.; Dijkstra, J.; France, J. Assessment of nutritive value of cereal and legume straws based on chemical composition and in vitro digestibility. J. Sci. Food Agric. 2005, 85, 1550-1557. [CrossRef]

14. Zhou, R.; Zhu, L.; Yang, K.; Chen, Y. Distribution of organochlorine pesticides in surface water and sediments from Qiantang River, East China. J. Hazard. Mater. 2006, 137, 68-75. [CrossRef] [PubMed]

15. Pimentel, D. Environmental and Economic Costs of the Application of Pesticides Primarily in the United States. Env. Dev. Sustain. 2005, 7, 229-252. [CrossRef]

16. Abhilash, P.C.; Singh, N. Pesticides use an application: An Indian Scenario. J. Hazard. Mater. 2009, 165, 1-12. [CrossRef] [PubMed]

17. Zhang, F.; He, J.; Yao, Y.; Hou, D.; Jiang, C.; Zhang, X.; Di, C.; Otgonbayar, K. Spatial and seasonal variations of pesticides contamination in agricultural soils and crops sample from an intensive horticulture area of Hohhot, North-West China. Env. Monit. Assess. 2013, 185, 6893-6908. [CrossRef] [PubMed] 
18. Bender, D.H.; Butham, K.M.; Kenelly, P.S.; Rodwell, U.W.; Weil, P.A. Harper's illustrated biochemistry. The McGraw-Hill Companies: Devon shire, UK, 2009; p. 704.

19. Dudka, S.; Miller, W.P. Permissible concentrations of arsenic and lead in soils based on risk assessment. Water Air Soil Pollut. 1999, 113, 127-132. [CrossRef]

20. Mishra, S.; Tiwari, A.; Shukla, B.; Seth, C.S. Effects of soil amendments on the bioavailability of heavy metals from zinc mine tailings. Environ. Monit. Assess. 2009, 155, 467-475.

21. Chopra, A.K.; Pathak, C. Bioaccumulation and translocation efficiency of heavy metals in vegetables grown on long-term wastewater irrigated soil near Bindal River, Dehradon. Agric. Res. 2012, 1, 157. [CrossRef]

22. Inaba, S.; Takenaka, C. Effects of dissolved organic matter on toxicity and bioavailability of copper for lettuce sprouts. Environ. Int. 2005, 31, 603-608. [CrossRef] [PubMed]

23. Chronopoulos, J.; Haidouti, C.; Chronopoulou-Sereli, A.; Massas, I. Variations in plant and soil lead and cadmium content in urban parks in Athens. Greece. Sci. Total Environ. 1997, 196, 91-98. [CrossRef]

24. Woyessa, G.W.; Kassa, S.B.; Demissie, E.G.; Srivastava, B.B.I. Determination of the level of some trace and heavy metals in some soft drinks of Ethiopia. Int. J. Curr. Res. Chem. Pham. Sci. 2015, 2, 84-88.

25. Wang, S.; Shi, X. Molecular mechanisms of metal toxicity and carcinogenesis. Mol. Cell. Biochem. 2001, 222, 3-9. [CrossRef] [PubMed]

26. Chang, L.W.; Magos, L.; Suzuki, T. Toxicology of Metals; CRC Press: Boca Raton, FL, USA, 1996; p. 1198.

27. Beyersmann, D.; Hartwig, A. Cic metal compounds: Rearcinogencent insight into molecular and cellular mechanisms. Arch. Toxicol. 2008, 82, 493-512. [CrossRef] [PubMed]

28. Salako, S.G.; Adekoyeni, O.O.; Adegbite, A.A.; Hammed, T.B. Determination of Metals Content of Alcohol and Non-alcoholic Canned Drinks Consumed at Idiroko Border Town, Ogun State, Nigeria. Br. J. Appl. Sci. Technol. 2016, 12, 1-8. [CrossRef]

29. Ogunlana, O.O.; Ogunlana, O.E.; Akinsanya, A.E.; Ologbenia, O.O. Heavy Metal analysis of selected soft drinks sold in Nigeria. J. Glob. Biosci. 2015, 4, 1335-1338.

30. Engwa, A.G.; Ihekwoaba, C.J.; Ilo, U.S.; Unaegbu, M.; Ayuk, L.; Osuji, A.G. Determination of some soft drink constituents and contamination by some heavy metals in Nigeria. Toxicol. Rep. 2015, 2, 384-390.

31. Al-Mudhaf, H.F.; Alzaid, H.M.; Abu-Shady, A.I. Study of trace and heavy metals content of soft drinks in the state of Kuwait. Int. J. Eng. Res. Appl. 2016, 6, 1-6.

32. Ofori, H.; Owusu, M.; Anyebuno, G. Heavy metal analysis of fruit juice and soft drinks brought from retail market in Accra, Ghana. Ghana J. Sci. Report. 2013, 2, 423-428.

33. Elbagermi, M.A.; Edwards, H.G.M.; Alajtal, A.I. Monitoring of heavy metal content in fruits and vegetables collected from production and market sites in the misurata area of libya. 2012, 2012, 1-5. [CrossRef]

34. European Union. Conucil Directives 1999/74/EC of 19 July 1999 Laying down Minimum standards for the protection of laying Hens. Available online: http:/ / eur-lex.europa.eu/legal-content/EN/TXT/?uri=celex\% 3A3199L0074-EN (accessed on 26 June 2018).

35. Saiyed, H.; Dewan, A.; Bhatnagav, V.; Shenoyl, U.; Shenoy, R.; Rajmohan, H.; Patel, K.; Kashyap, K.; Kulkarni, P.; Rajan, B.; et al. Effect of endosulfan on male reproductive development. Environ. Health Perspect. 2003, 111, 1958-1962. [CrossRef] [PubMed]

36. Pathek, R.; Sanvidhanh, G.S.; Uke, S.G.; Tanzeel Ahmed, T.; Rafat, S.; Ahmed, R.S.; Tripathi, A.K.; Guleria, K.; Sharma, C.S.; Makhijani, S.D.; et al. Organochlorine pesticides residue levels and oxidative stress in Pre-Tern Delivery Cases. Hum. Exp. Toxicol. 2010, 29, 351-358. [CrossRef] [PubMed]

37. Ibigbami, O.A.; Adebawore, A.A. Persistent organochlorine pesticide residues in some selected Cocoa beverages in Nigeria. Beverages 2017, 3, 60. [CrossRef]

38. Aikpokpodion, P.E.; Lajide, L.; Aiyesanmi, A.F. Characterization of heavy metal fractions in agricultural soils using sequential extraction technique. World J. Agric. Sci. 2013, 9, 45-52.

(C) 2018 by the authors. Licensee MDPI, Basel, Switzerland. This article is an open access article distributed under the terms and conditions of the Creative Commons Attribution (CC BY) license (http://creativecommons.org/licenses/by/4.0/). 